\title{
Study on the physical properties of $\mathrm{Cu}_{2} \mathrm{ZnSnS}_{4}$ thin films deposited by pneumatic spray pyrolysis technique
}

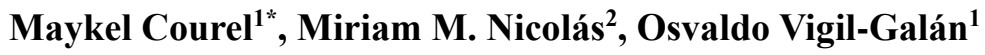 \\ ${ }^{1}$ Instituto de Energías Renovables, Universidad Nacional Autónoma de México, Temixco, Morelos 62580, Mexico. \\ E-mail: maykelcourel@gmail.com \\ ${ }^{2}$ Escuela Superior de Física y Matemáticas-Instituto Politécnico Nacional (IPN), C.P. 07738, CDMX, México
}

\begin{abstract}
The acquisition of new materials for the manufacturing of high efficiency and low-cost photovoltaic devices has currently become a challenge. Thin films of CuInGaSe and CdTe have been widely used in solar cell of second generation, achieving efficiencies about $20 \%$; however, the low abundance of In and Te as well as the toxicity of Cd is the primary obstacles to their industrial production. Compounds such as $\mathrm{Cu}_{2} \mathrm{ZnSnS}_{4}, \mathrm{Cu}_{2} \mathrm{ZnSnSe}_{4}$ and $\mathrm{Cu}_{2} \mathrm{ZnSn}(\mathrm{SSe})_{4}$ have emerged as an important and less costly alternative for efficient energy conversion in the future. In addition, these compounds have the required characteristics to be used as an absorber material in solar cells (band-gap close to $1.4 \mathrm{eV}$, an absorption coefficient greater than $10^{4} \mathrm{~cm}^{-1}$ and a p-type conductivity). In this work, we present a study of the structural, compositional, morphological and optical properties of $\mathrm{Cu}_{2} \mathrm{ZnSnS}_{4}$ thin films deposited by spray pyrolysis technique as well as their dependence on temperature.
\end{abstract}

Keywords: CZTS; Thin Films; Solar Cells; Structural; Morphological; Compositional and Optical Properties

\section{ARTICLE INFO}

Received: 6 March 2021

Accepted: 20 April 2021

Available online: 27 April 2021

\section{COPYRIGHT}

Copyright $\odot 2021$ Maykel Courel et al. EnPress Publisher LLC. This work is licensed under the Creative Commons Attribution-NonCommercial 4.0 International License (CC BY-NC 4.0).

https://creativecommons.org/licenses/by-nc/ $4.0 /$

\section{Introduction}

Currently, solar cells have not yet been able to replace fossil fuels. To obtain a greater contribution of photovoltaic energy in the energy market, it is necessary to reduce production costs as well as increase the efficiency of the cells. Within the field of photovoltaics, solar cells of second generation have reduced production costs. Among the most used materials, CdTe and CuInGaSe have been able to achieve efficiencies greater than $18 \%{ }^{[1]}$. However, the shortage of In and Te and the high toxicity of $\mathrm{Cd}$ have been major obstacles to industrial production. For this reason, it is necessary to search for new materials with adequate physical properties for their application in photovoltaics. An alternative that has been studied is the kesterite compound $\mathrm{Cu}_{2} \mathrm{ZnSnS}_{4}$ (CZTS), which meets the requirements to be used as an absorber, that is, a band gap of $1.4 \mathrm{eV}$, p-type conductivity, in addition to having an absorption coefficient greater than $10^{4} \mathrm{~cm}^{-1[2-6]}$.

Different deposition techniques have been considered to CZTS thin films deposition for solar cells application. In particular, thermal evaporateion $^{[7]}$, co-evaporation ${ }^{[8]}$, magnetron sputtering ${ }^{[9,10]}$, screen printed $^{[11]}$, sol gel ${ }^{[12]}$, electrodeposition ${ }^{[13]}$, photochemical deposition ${ }^{[14]}$, and spray pyrolysis ${ }^{[15-20]}$ are among the most used ones. These techniques offer an easy and cheap route for thin film processing. Particularly, spray pyrolysis constitutes an easy, economical and versatile technique which is potentially attractive to reduce cost of solar cell 
processing. In regardless of the deposition method used to obtain the kesterite, it has been shown that film compositions must meet certain non-stoichiometric conditions to achieve high efficiencies in cells $(\mathrm{Cu} /(\mathrm{Zn}+\mathrm{Sn}) \approx 0.85$ and $\mathrm{Zn} / \mathrm{Sn} \approx$ $1.25)^{[21]}$. Therefore, this consideration must be taken into account for the deposition of the films.

In this work, a study of the dependence of the structural, morphological and optical properties of CZTS thin films deposited by the chemical spray pyrolysis method as a function of temperature is presented. In addition, the relationship of these properties with the $\mathrm{Cu} /(\mathrm{Zn}+\mathrm{Sn})$ and $\mathrm{Zn} / \mathrm{Sn}$ compositional ratios will be presented.

\section{Experimental details}

CZTS films were deposited by the chemical spray pyrolysis method. The method consists of mixing different reagents in a solution and then spraying it. The substrate is placed on heated plate where the reaction is carried out. The temperature of the heated plate is controlled by a thermocouple. Once the substrate is heated, the solution is sprayed with the help of a compressor using air as carrier gas. The temperature of the substrate stands out as one of the most important parameters to be taken into account.

\subsection{Solution preparation}

For the deposition of CZTS films by means of the chemical spray pyrolysis technique, the precursor salts $\left(\mathrm{CH}_{3} \mathrm{COO}\right)_{2} \mathrm{Zn} * 2 \mathrm{H}_{2} \mathrm{O}, \mathrm{CuCl}_{2}, \mathrm{SnCl}_{4} *$ $\mathrm{H}_{2} \mathrm{O}$ and thiourea were considered. All the salts are dissolved in $50 \mathrm{ml}$ of deionized water. The masses of the salts to be diluted were calculated to obtain the optimal composition ratios ${ }^{[21]}$, resulting: 132.8 $\mathrm{mg}$ of $\mathrm{Cu}, 107.6 \mathrm{mg}$ of $\mathrm{Zn}, 87.9 \mathrm{mg}$ of $\mathrm{Sn}$ and 134.7 $\mathrm{mg}$ of S. $50 \%$ of the solution is extracted of each salt, adding $100 \mathrm{ml}$ of deionized water, obtaining in this way a $200 \mathrm{ml}$ solution, which is the one used for the deposition.

\subsection{Thin film deposition}

A flow rate of $5 \mathrm{ml} / \mathrm{min}$, a pressure of $10 \mathrm{Psi}$, with a separation distance between the nozzle and the substrate of approximately $30 \mathrm{~cm}$ and a temperature range of $400-440{ }^{\circ} \mathrm{C}$ were considered. More specifically, we worked with $400{ }^{\circ} \mathrm{C}, 420{ }^{\circ} \mathrm{C}$ and $440{ }^{\circ} \mathrm{C}$. All films were deposited under the same growth conditions mentioned above, with a deposition time of 20 minutes for each sample.

\subsection{Characterization}

CZTS thin films processed by spray pyrolysis were submitted to the following characterizations: X-ray diffraction (X'PertPRO-MRD (PW3050/65) diffractometer from Panalytical using $\mathrm{CoK} \alpha$ radiation), Transmittance (Lambda 35 UV/VIS PerkinElmer) and SEM and EDS by Jeol JSM-7800F with an accelerating voltage of $30 \mathrm{keV}$. By means of these characterizations, it is possible to find the type of structure, the atomic composition as well as the band gap.

\section{Results}

\subsection{X-RAY Diffraction Results}

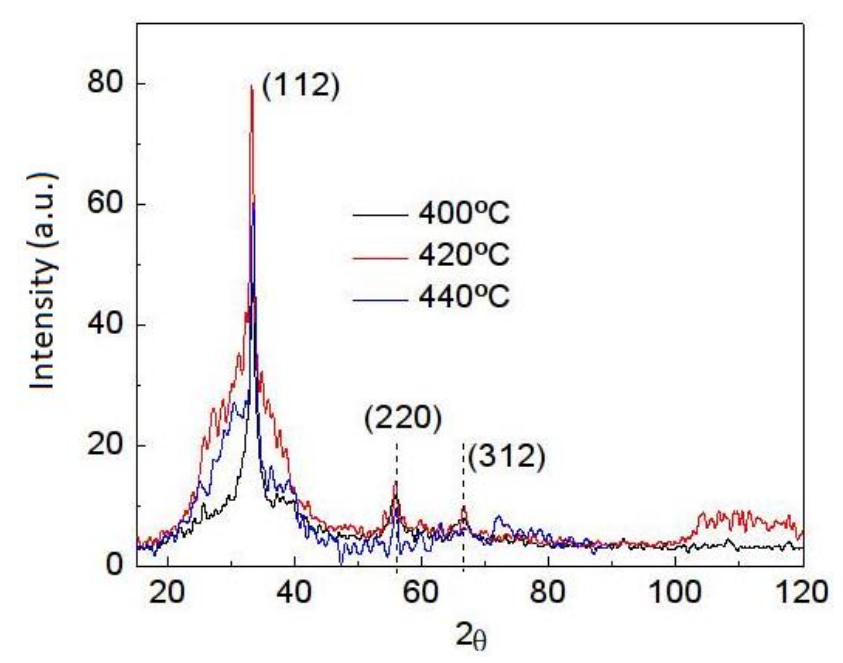

Figure1. XRD patterns of CZTS compound where the contribution of 3 planes can be observed.

Figure 1 shows the results of $\mathrm{X}$-ray diffraction for films grown at temperatures of $400{ }^{\circ} \mathrm{C}, 420{ }^{\circ} \mathrm{C}$ and $440{ }^{\circ} \mathrm{C}$. The measurements were made with the help of a cobalt source $(\mathrm{K} \alpha)$. We know from Bragg's law on X-ray diffraction that ${ }^{[4]}$ :

$d \sin \theta=\lambda$

With the help of equation 1 we can find the interplanar distances $(d)$. Taking into account that the CZTS compound has an orthorhombic structure with lattice parameters: $a=b=5.427 \AA$ and $c=$ $10.848 \AA$, with the help of equation (2), the Miller indices of the planes $(h, k, l)$ can be calculated. 
$\frac{1}{d^{2}}=\frac{h^{2}+k^{2}}{a^{2}}+\frac{l^{2}}{c^{2}}$

Table 1. Miller indices

\begin{tabular}{ll} 
& Table 1. Miller indices \\
\hline $\mathbf{2 0}$ & Miller indices \\
\hline 33.3 & $(112)$ \\
55.7 & $(220)$ \\
66.8 & $(312)$ \\
\hline
\end{tabular}

The results for different temperatures are shown in Table 1. The main planes that contribute to X-ray diffraction are (112), (220) and (312) which can be attributed to the compound $\operatorname{CZTS}^{[17,22]}$. Although the film grown at $420{ }^{\circ} \mathrm{C}$ showed a greater contribution to the diffraction of the plane (112) in Figure 1, the film grown at $400{ }^{\circ} \mathrm{C}$ has a better crystalline quality. As an important result, Figure 1 showed that the grown films are not amorphous with the formation of the CZTS compound, which will be corroborated by the optical absorption measurements. Degradation in both peak intensity and crystalline quality is observed from Figure 1 when temperature is increased from 420 to $440{ }^{\circ} \mathrm{C}$, which could be a result of re-evaporation of some elements such as Sn and S under a relatively higher growth temperature.

\subsection{EDS and SEM results}

\subsubsection{Film deposited at $400{ }^{\circ} \mathrm{C}$}

For this case, a sulfur composition (S) of $29.6 \%$ is obtained, which is lower than the required for the compound stoichiometry, while $\mathrm{Cu} /(\mathrm{Zn}+\mathrm{Sn})$ and $\mathrm{Zn} / \mathrm{Sn}$ compositional ratios were:

$$
\begin{aligned}
& \frac{C_{u}}{Z_{n}+S_{n}} \sim 0.85 \\
& \frac{Z_{n}}{S_{n}} \sim 1.03
\end{aligned}
$$

It is also important to highlight the fact that compositions close to the stoichiometric are obtained for the temperature of $400{ }^{\circ} \mathrm{C}$. Despite $\mathrm{Cu}$-poor samples are obtained, the condition of $\mathrm{Zn}$-rich samples is not fulfilling which could result in the formation of poor crystalline quality as previously demonstrated ${ }^{[22]}$. Therefore, for this temperature the optimum compositions relationships were not achieved.

\subsubsection{Film deposited at $420^{\circ} \mathrm{C}$}

At this temperature, 39\% sulfur composition

was achieved, while $\mathrm{Cu} /(\mathrm{Zn}+\mathrm{Sn})$ and $\mathrm{Zn} / \mathrm{Sn}$ compositional ratios were:

$$
\begin{aligned}
& \frac{C_{u}}{Z_{n}+S_{n}} \sim 0.84 \\
& \frac{Z_{n}}{S_{n}} \sim 1.16
\end{aligned}
$$

It is important to note that an increase in the composition of $\mathrm{S}$ was obtained with respect to the film deposited at $400{ }^{\circ} \mathrm{C}$. Also, compositional ratios close to optimal ones were obtained; therefore, $420{ }^{\circ} \mathrm{C}$ could be more suitable as the substrate temperature for depositing CZTS films in order to be applied in solar cells.

\subsubsection{Film deposited at $440{ }^{\circ} \mathrm{C}$}

With the increase of the temperature to $440{ }^{\circ} \mathrm{C}$, it is obtained that the concentration of $\mathrm{S}$ decreased to $35.1 \%$, for which more losses of this element are obtained with respect to the film deposited at $420{ }^{\circ} \mathrm{C}$, which could be a result of sulfur losses for higher temperatures. In addition, $\mathrm{Cu} /(\mathrm{Zn}+\mathrm{Sn})$ and $\mathrm{Zn} / \mathrm{Sn}$ compositional ratios are found to be out of the optimum as shown below:

$$
\begin{aligned}
& \frac{c_{u}}{z_{n}+S_{n}} \sim 0.61 \\
& \frac{z_{n}}{S_{n}} \sim 1.1
\end{aligned}
$$

In particular, it is observed that for this temperature the sample is much poorer in $\mathrm{Cu}$ than the value corresponding to the optimum.

Figure 2 shows the comparison of the morphology of the three films that were deposited at $400{ }^{\circ} \mathrm{C}, 420{ }^{\circ} \mathrm{C}$ and $440{ }^{\circ} \mathrm{C}$. The morphology is highly dependent on temperature. The film deposited at $400{ }^{\circ} \mathrm{C}$ illustrates the formation of some porous, while increasing the temperature favors the formation of clusters bigger in size.

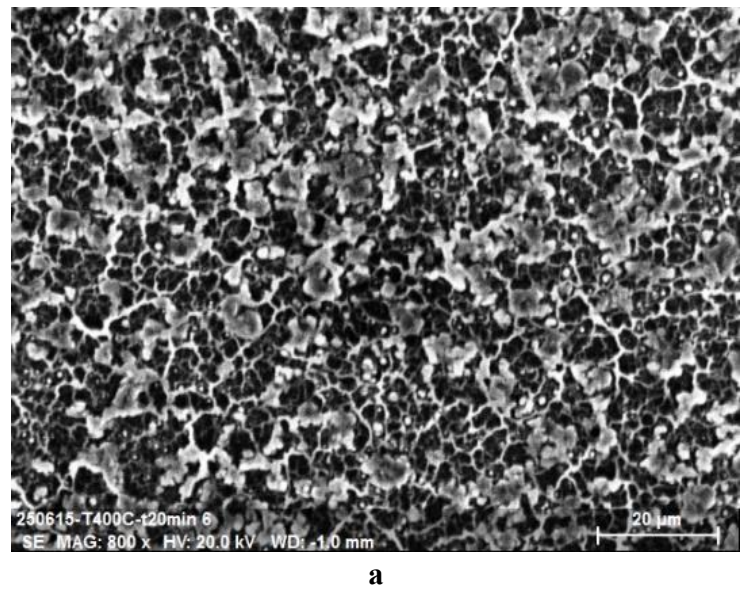



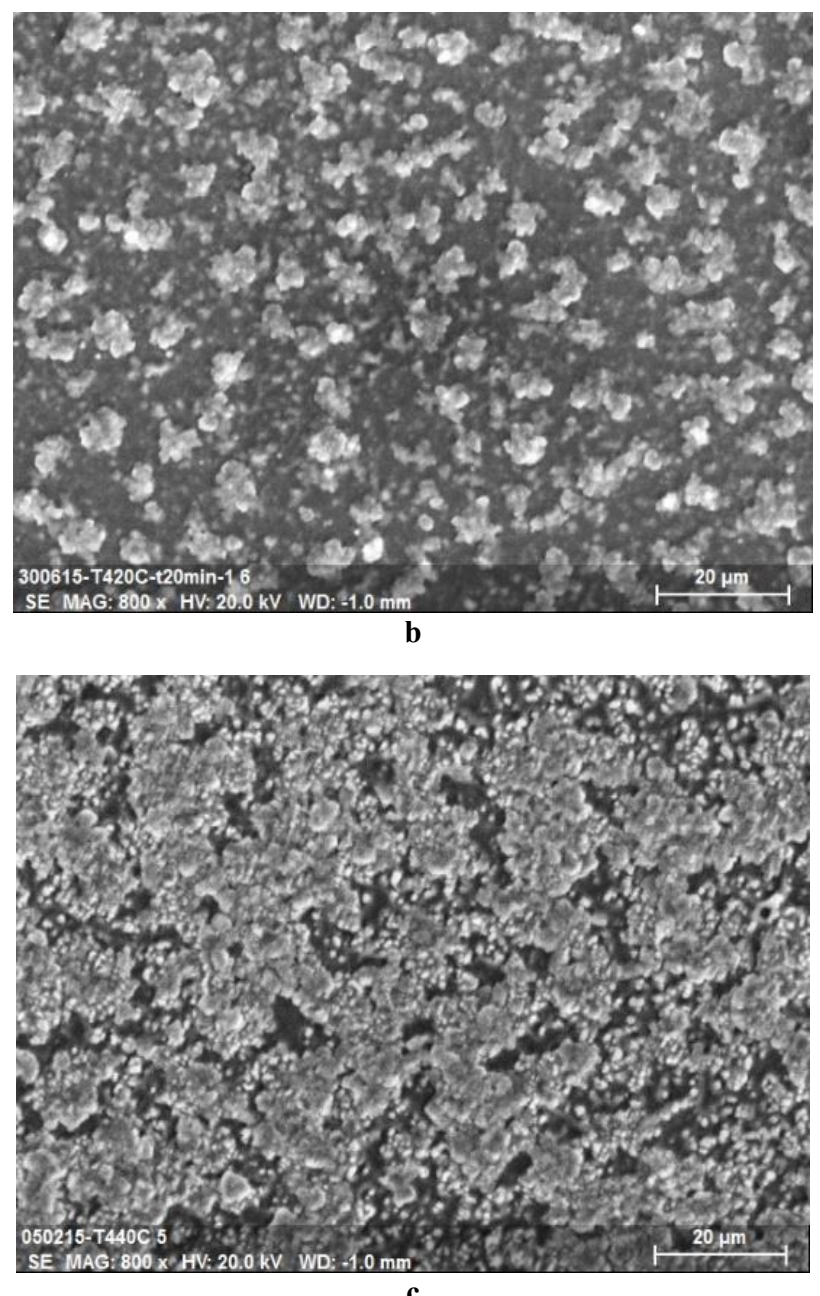

Figure 2. Morphological comparison (800x) of the films at $400{ }^{\circ} \mathrm{C}(\mathbf{a}), 420^{\circ} \mathrm{C}(\mathbf{b})$ and $440{ }^{\circ} \mathrm{C}(\mathbf{c})$.

\subsection{Transmittance}

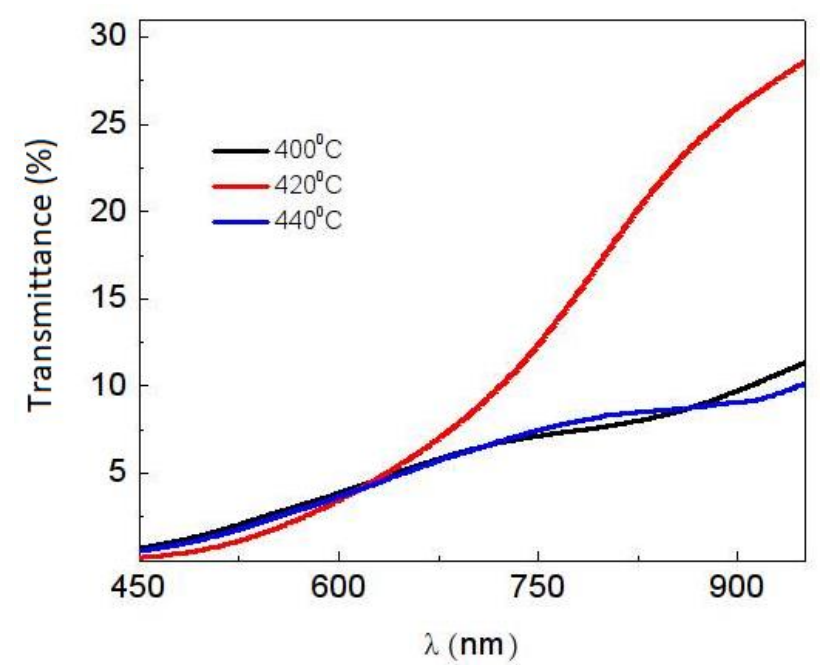

Figure 3. Transmittance of thin films deposited at temperatures of $400{ }^{\circ} \mathrm{C}, 420^{\circ} \mathrm{C}, 440{ }^{\circ} \mathrm{C}$.

Figure 3 shows results of the measured transmittances of the films. The transmittance value in all cases was less than $30 \%$, which confirms the potential of the $\mathrm{Cu}_{2} \mathrm{ZnSnS}_{4}$ material as an absorber. Figure 4 shows the band gap calculated from the derivative of transmittance. The possible contributions of secondary phases to absorption are illustrated for samples deposited under 400 and $440{ }^{\circ} \mathrm{C}$. For the substrate temperature of $420{ }^{\circ} \mathrm{C}$, a greater contribution of the CZTS material is obtained which corroborates the results obtained in composition and XRD.

\section{Discussion}

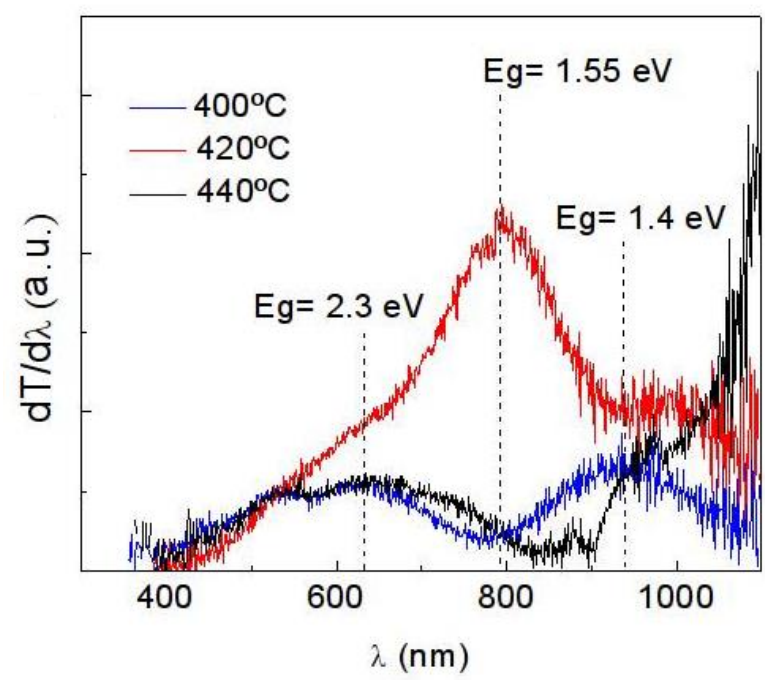

Figure 4. Derivative of transmittance measurements as a function of wavelength for band-gap estimation.

From XRD, EDS and transmittance results, it is found that sample deposited under a substrate temperature of $420{ }^{\circ} \mathrm{C}$ is more adequate for solar cell applications. When depositing the CZTS compound starting from precursors containing the four salts $(\mathrm{Cu}, \mathrm{S}, \mathrm{Sn}, \mathrm{Zn})$, in addition to forming the desired compound $\mathrm{Cu}_{2} \mathrm{ZnSnS}_{4}$, other secondary phases can be formed, which lower the efficiency of the cells. The formation of secondary phases can explain the other contributions to absorption obtained in Figure 4. In particular, a band gap value close to $2.3 \mathrm{eV}$ is commonly associated with secondary phases of $\mathrm{Cu}-\mathrm{S}$ compounds ${ }^{[23]}$. Therefore, the film grown at $420{ }^{\circ} \mathrm{C}$ has a lower contribution of secondary phases. The $\mathrm{Cu}_{2} \mathrm{ZnSnS}_{4}$ must have an atomic composition of $50 \%$ in Sulfur, but because there are some losses due to its high volatility, this composition is always less than $50 \%$ unless samples were submitted to a post-thermal annealing under $\mathrm{S}$ atmosphere. Therefore, according to the SEM study, 
the most optimal film is the one that was grown at a temperature of $420{ }^{\circ} \mathrm{C}$ and not only because of the percentage of sulfur but also because of $\mathrm{Cu} /(\mathrm{Zn}+\mathrm{Sn})$ and $\mathrm{Zn} / \mathrm{Sn}$ compositional ratios that correspond to an optimized efficiency for this compound as previously demonstrated. On the other hand, the higher the uniformity of the film is, the greater the efficiency of the cell is. According to Figure 2, the uniformity increases when the temperature is higher; therefore, for the temperature of $440{ }^{\circ} \mathrm{C}$ there are fewer holes (Figure 2c) than with the temperature $400{ }^{\circ} \mathrm{C}$ (Figure 2a) and $420{ }^{\circ} \mathrm{C}$ (Figure 2b). However, it was already discussed that for this temperature $\left(440{ }^{\circ} \mathrm{C}\right)$, sample is very $\mathrm{Cu}$-poor and therefore the $\mathrm{Cu} /(\mathrm{Zn}+\mathrm{Sn})$ and $\mathrm{Zn} / \mathrm{Sn}$ compositional ratios are out of the optimum which will reduce solar cell efficiency. In addition, the samples showed a transmittance of less than $30 \%$ which, due to being an absorbing material, it is expected to have a low transmittance (see Figure 3). Among the three temperatures, the $420{ }^{\circ} \mathrm{C}$ has a better behavior in the transmittance with the wavelength since the derivative (see Figure 4) has a peak that corresponds to a band gap of $1.5 \mathrm{eV}$ corresponding to the $\operatorname{CZTS}^{[23,24]}$.

\section{Conclusions}

In this work, a study of the structural, compositional, morphological and optical properties of CZTS films deposited under different substrate temperatures was presented, demonstrating the high dependence of these properties with substrate temperature. It was shown that when working with 4 elements to form the compound $\mathrm{Cu}_{2} \mathrm{ZnSnS}_{4}$, there is a high probability of the formation of secondary phases. Therefore, it is necessary to study the conditions under which these secondary phases are minimized, since the lower the contribution of these phases, the greater the efficiency of the solar cell. The results showed that the film deposited at a temperature of $420{ }^{\circ} \mathrm{C}$ has better properties to be applied in solar cells (band gap of $1.5 \mathrm{eV}$, a composition of sulfur of $39 \%$ as well as $\mathrm{Cu} /(\mathrm{Zn}+\mathrm{Sn})$ and $\mathrm{Zn} / \mathrm{Sn}$ compositional ratios close to the optimum).

\section{Conflict of interest}

The authors declare that they have no conflict of interest.

\section{Acknowledgements}

O. Vigil thanks support from COFAA and EDI of IPN.

\section{References}

1. Green MA, Emery K, Hishikawa Y, et al. Solar cell efficiency tables (version 43). Progress in Photovoltaics: Research and Applications 2013; 22(1): 1-9.

2. Lee YS, Gershon T, Gunawan $\mathrm{O}$, et al. $\mathrm{Cu}_{2} \mathrm{ZnSnSe}_{4}$ thin-film solar cells by thermal co-evaporation with $11.6 \%$ efficiency and improved minority carrier diffusion length. Advanced Energy Materials 2014; 5(7): 1401372.

3. Gunawan O, Todorov TK, Mitzi DB. Loss mechanisms in hydrazine-processed $\mathrm{Cu}_{2} \mathrm{ZnSn}(\mathrm{Se}, \mathrm{S})_{4}$ solar cells. Applied Physics Letters 2010; 97(23): 233506.

4. Siebentritt S. Why are kesterite solar cells not $20 \%$ efficient? Thin Solid Films 2013; 535: 1-4.

5. Gokmen T, Gunawan O, Todorov TK, et al. Band tailing and efficiency limitation in kesterite solar cells. Applied Physics Letters 2013; 103: 103506.

6. Polizzotti A, Repins IL, Noufi R, et al. The state and future prospects of kesterite photovoltaics. Energy \& Environmental Science 2013; 6: 3171-3182.

7. Tanaka T, Kawasaki D, Nishio M, et al. Fabrication of $\mathrm{Cu}_{2} \mathrm{ZnSnS}_{4}$ thin films by co-evaporation. Physical Status Solidi (C) 2006; 3(8): 2844-2847.

8. Babu GS, Kumar YBK, Bhaskar PU, et al. Effect of $\mathrm{Cu} /(\mathrm{Zn}+\mathrm{Sn})$ ratio on the properties of co-evaporated $\mathrm{Cu} 2 \mathrm{ZnSnSe} 4$ thin films. Solar Energy Materials and Solar Cells 2010; 94: 221-226.

9. Fairbrother A, Fontané X, Izquierdo-Roca V, et al. Single-step sulfo-selenization method to synthesize $\mathrm{Cu}_{2} \mathrm{ZnSn}(\mathrm{SySe} 1-\mathrm{y})_{4}$ absorbers from metallic stack precursors. ChemPhysChem 2013; 14(9): 18361843.

10. Katagiri H, Jimbo K, Shwe Maw WIN, et al. Development of CZTS based thin film solar cells. Thin Solid Films 2009; 517(7): 2455-2460.

11. Zhou Z, Wang Y, Xu D, et al. Fabrication of $\mathrm{Cu}_{2} \mathrm{ZnSnS}_{4}$ screen printed layers for solar cells. Solar Energy Materials \& Solar Cells 2010; 94: 20422045.

12. Moritake N, Fukui Y, Oonuki M, et al. Preparation of $\mathrm{Cu}_{2} \mathrm{ZnSnS}_{4}$ thin film solar cells under non-vacuum condition. Physica Status Solidi C 2009; 6: 1233-1236.

13. Scragg JJ, Dale PJ, Peter LM, et al. New routes to sustainable photovoltaics: evaluation of $\mathrm{Cu}_{2} \mathrm{ZnSnS}_{4}$ as an alternative absorber material. Physica Status Solidi B 2008; 245(9): 1772-1778.

14. Moriya K, Watabe J, Tanaka K, et al. Characterization of $\mathrm{Cu}_{2} \mathrm{ZnSnS}_{4}$ thin films prepared by photo-chemical deposition. Physica Status Solidi C 2006; 3(8): 2848-2852.

15. Courel M, Valencia-Resendiz E, Pulgarín-Agudelo 
FA, et al. Determination of minority carrier diffusion length of sprayed- $\mathrm{Cu}_{2} \mathrm{ZnSnS}_{4}$ thin films. Solid State Electron 2016; 118: 1-3.

16. Courel M, Valencia-Resendiz E, Arvizu JA, et al. Solar Energy Materials and Solar Cells 2017; 159: 151-158.

17. Courel M, Andrade-Arvizu JA, Guillén-Cervantes A, et al. Optimization of physical properties of spray-deposited $\mathrm{Cu}_{2} \mathrm{ZnSnS}_{4}$ thin films for solar cell applications. Materials \& Design 2017; 114: 515520.

18. Nakayama N, Ito K. Sprayed films of stannite $\mathrm{Cu}_{2} \mathrm{ZnSnS}_{4}$. Applied Surface Science 1996; 92: 171175.

19. Kamoun N, Bouzouita H. Fabrication and characterization of $\mathrm{Cu}_{2} \mathrm{ZnSnS}_{4}$ thin films deposited by spray pyrolysis technique. Thin Solid Films 2007; 515: 5949-5952.

20. Madarász J, Bombicz P, Okuya M, et al. Thermal decomposition of thiourea complexes of $\mathrm{Cu}(\mathrm{I})$,
$\mathrm{Zn}(\mathrm{II})$, and $\mathrm{Sn}(\mathrm{II})$ chlorides as precursors for the spray pyrolysis deposition of sulfide thin films. Solid State Ionics 2001; 141-142: 439-446.

21. Katagiri H, Jimbo K, Tahara M, et al. The influence of the composition ratio on CZTS-based thin film solar cells. Materials Research Society Symposium Proceedings 2009; 1165: M01-M04.

22. Courel M, Picquart M, Arce-Plaza A, et al. Study on the impact of stoichiometric and optimal compositional ratios on physical properties of $\mathrm{Cu} 2 \mathrm{ZnSnS} 4$ thin films deposited by spray pyrolysis. Materials Research Express 2018; 5: 015513.

23. Vigil-Galan O, Courel M, Espindola-Rodriguez M, et al. Toward a high $\mathrm{Cu}_{2} \mathrm{ZnSnS}_{4}$ solar cell efficiency processed by spray pyrolysis method. Journal of Renewable and Sustainable Energy 2013; 5: 053137.

24. Kumar YBK, Bhaskar PU, Babu GS, et al. Effect of copper salt and thiourea concentrations on the formation of $\mathrm{Cu} 2 \mathrm{ZnSnS} 4$ thin films by spray pyrolysis. Physica Status Solidi (A) 2010; 207 (1): 149-156. 